\title{
Measurement report: Ice nucleating abilities of biomass burning, African dust, and sea spray aerosol particles over the Yucatan Peninsula
}

Fernanda Córdoba ${ }^{1,2, *}$, Carolina Ramirez-Romero ${ }^{1,3, *}$, Diego Cabrera ${ }^{1}$, Graciela B. Raga ${ }^{1}$, 5 Javier Miranda ${ }^{4}$, Harry Alvarez Ospina ${ }^{5}$, Daniel Rosas ${ }^{6}$, Bernardo Figueroa ${ }^{7}$, Jong Sung $\mathrm{Kim}^{8}$, Jacqueline Yakobi-Hancock ${ }^{8}$, Talib Amador ${ }^{6}$, Wilfrido Gutierrez ${ }^{1, \dagger}$, Manuel García ${ }^{1}$, Allan K. Bertram ${ }^{9}$, Darrel Baumgardner ${ }^{10}$, and Luis A. Ladino ${ }^{1, *}$

${ }^{1}$ Centro de Ciencias de la Atmósfera, Universidad Nacional Autónoma de México, México

10 City, México

${ }^{2}$ Posgrado en Ciencias Química, Universidad Nacional Autónoma de México, México City, México

${ }^{3}$ Posgrado en Ciencias de la Tierra, Universidad Nacional Autónoma de México, México City, México

$15{ }^{4}$ Instituto de Física, Universidad Nacional Autónoma de México, México City, México

${ }^{5}$ Facultad de Ciencias, Universidad Nacional Autónoma de México, México City, México

${ }^{6}$ Facultad de Química, Universidad Autónoma de Yucatán, Mérida, México

${ }^{7}$ Instituto de Ingeniería, Unidad Académica de Sisal, Universidad Nacional Autónoma de México, Sisal, México

$20{ }^{8}$ Dalhousie University, Halifax, Nova Scotia, Canada

${ }^{9}$ Chemistry Department, University of British Columbia, Vancouver, Canada

${ }^{10}$ Droplet Measurement Technologies, Colorado, US

$\dagger$ Deceased

*These authors contributed equally to this work

$25 \quad{ }^{* *}$ Correspondence to: Luis A. Ladino (luis.ladino@atmosfera.unam.mx) 


\section{Supplementary information}

40 Table S1. Summary of a subset of samples taken from Merida and Sisal during 2017 and 2018 to analyze the results presented in this study. MA, BB, and AD refer to marine aerosol, biomass burning, and African dust, respectively. *two samples were collected at different times during the same day.

\begin{tabular}{|c|c|c|}
\hline Aerosol Type & Place & Date \\
\hline \multirow{7}{*}{ MA } & \multirow{7}{*}{ Sisal } & $24-01-2017 *$ \\
\hline & & $24-01-2017 *$ \\
\hline & & $25-01-2017$ \\
\hline & & $26-01-2017$ \\
\hline & & $27-01-2017$ \\
\hline & & $28-01-2017$ \\
\hline & & 29-01-2017 \\
\hline \multirow{5}{*}{$\mathrm{BB}$} & \multirow{5}{*}{ Merida } & $27-05-2017$ \\
\hline & & 03-04-2018 \\
\hline & & 05-04-2018 \\
\hline & & 06-04-2018 \\
\hline & & 08-04-2018 \\
\hline \multirow{8}{*}{$\mathrm{AD}$} & \multirow{4}{*}{ Sisal } & $11-07-2018$ \\
\hline & & $12-07-2018$ \\
\hline & & $13-07-2018$ \\
\hline & & $15-07-2018$ \\
\hline & \multirow{4}{*}{ Merida } & 11-07-2018 \\
\hline & & $13-07-2018$ \\
\hline & & 14-07-2018 \\
\hline & & $16-07-2018$ \\
\hline
\end{tabular}

(a)

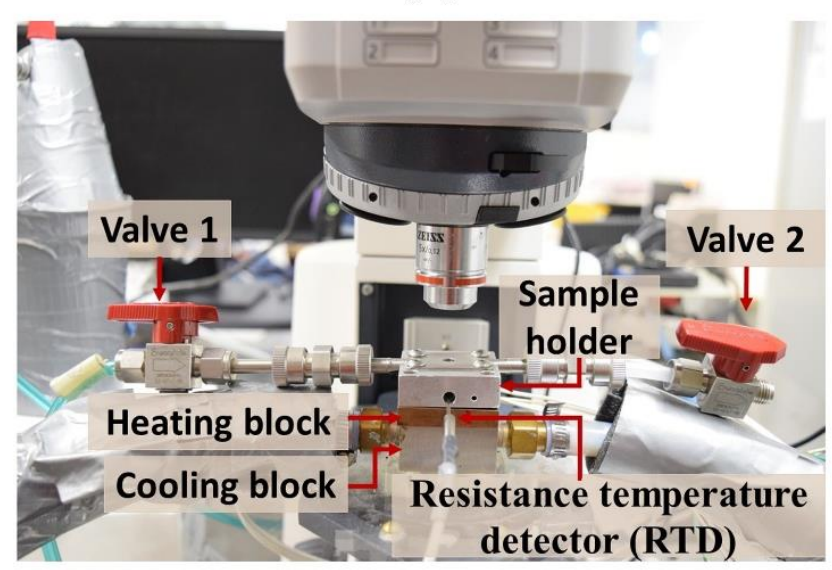

(b) Viewing area of microscope $\left(1.2 \mathrm{~mm}^{2}\right)$

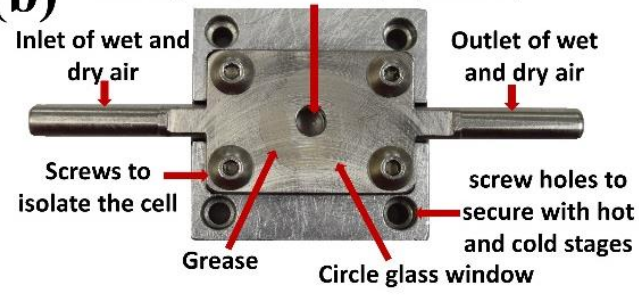

(c)

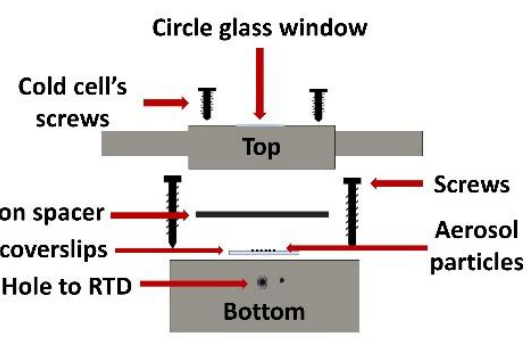


45 Figure S1. (a) Cold stage showing the sample holder, the heating block, and the cold block (b) a top view of the sample holder, and (c) a schematic diagram of a front view of the sample holder.

(a)

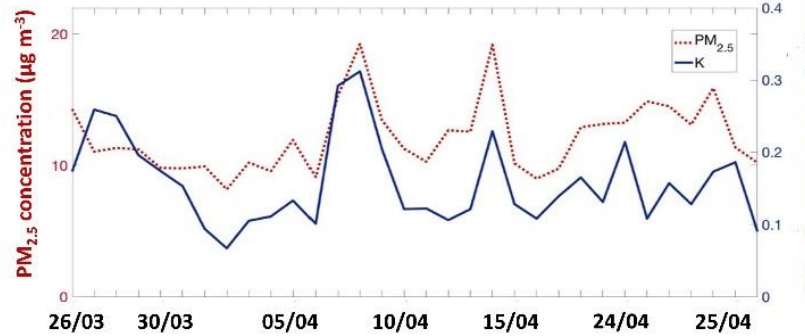

(b)

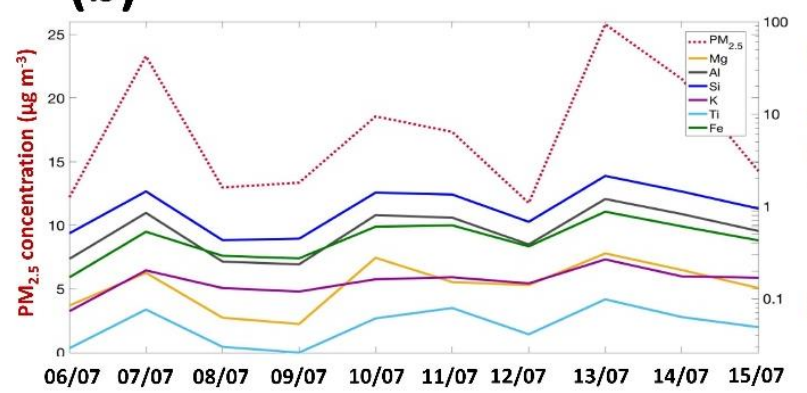

(c)

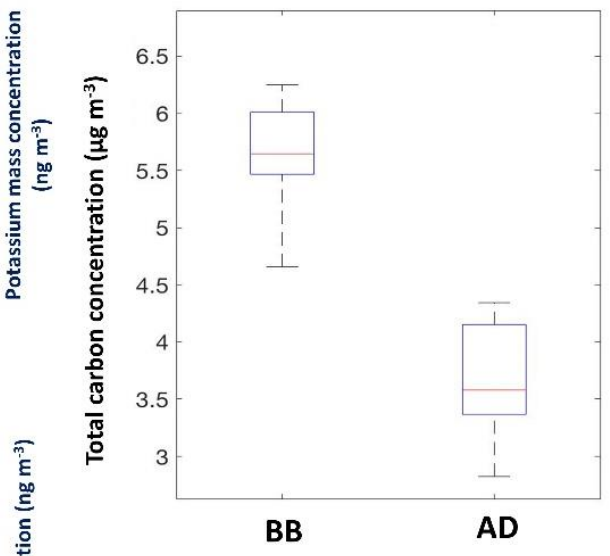

Figure S2. Mass concentration of $\mathrm{PM}_{2.5}$ and chemical elements by XRF (a) BB $K_{P . C^{*}} \geq 0.60$, (b) AD $\mathrm{Mg}_{\text {P.C }} \geq 0.82, \mathrm{Al}_{\text {P.C }} \geq 0.94, \mathrm{Si}_{\text {P.C }} \geq 0.94, \mathrm{~K}_{\text {P.C }} \geq 0.86, \mathrm{Ti}_{\text {P.C }} \geq 0.89, \mathrm{Fe}_{\text {P.C }} \geq 0.88$ and, (c) total carbon concentration for $\mathrm{BB}$ and $\mathrm{AD} . *$ P.C $=$ Pearson correlation

(a) NOAA HYSPLIT MODEL Backward trajectories ending at 1200 UTC 29 Jan 17 GFSG Meteorological Data

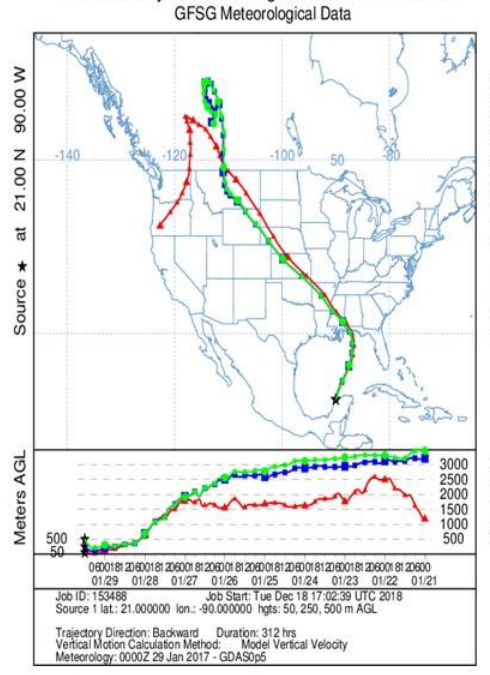

(b) NOAA HYSPLIT MODEL
Backward trajectories ending at 2000 UTC 10 Jul 18

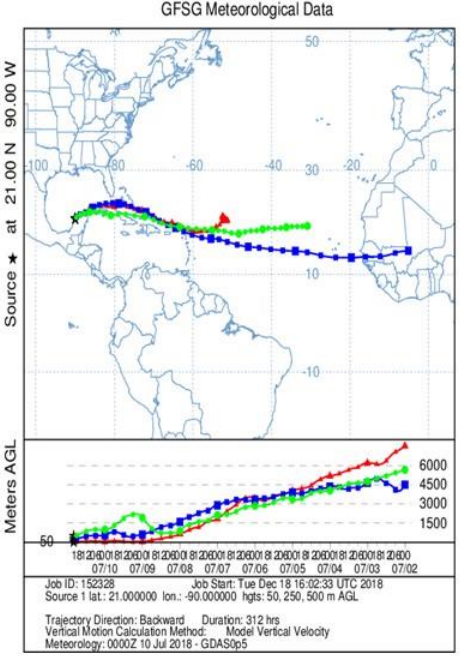

(c)

NOAA HYSPLIT MODEL

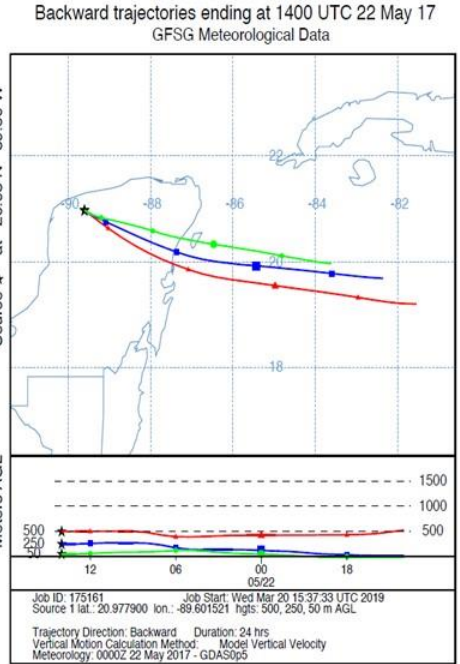

Figure S3. HYSPLIT back trajectories for the three different air masses (a) MA-2017, (b) SD-2018, and (c) BB-2017. 

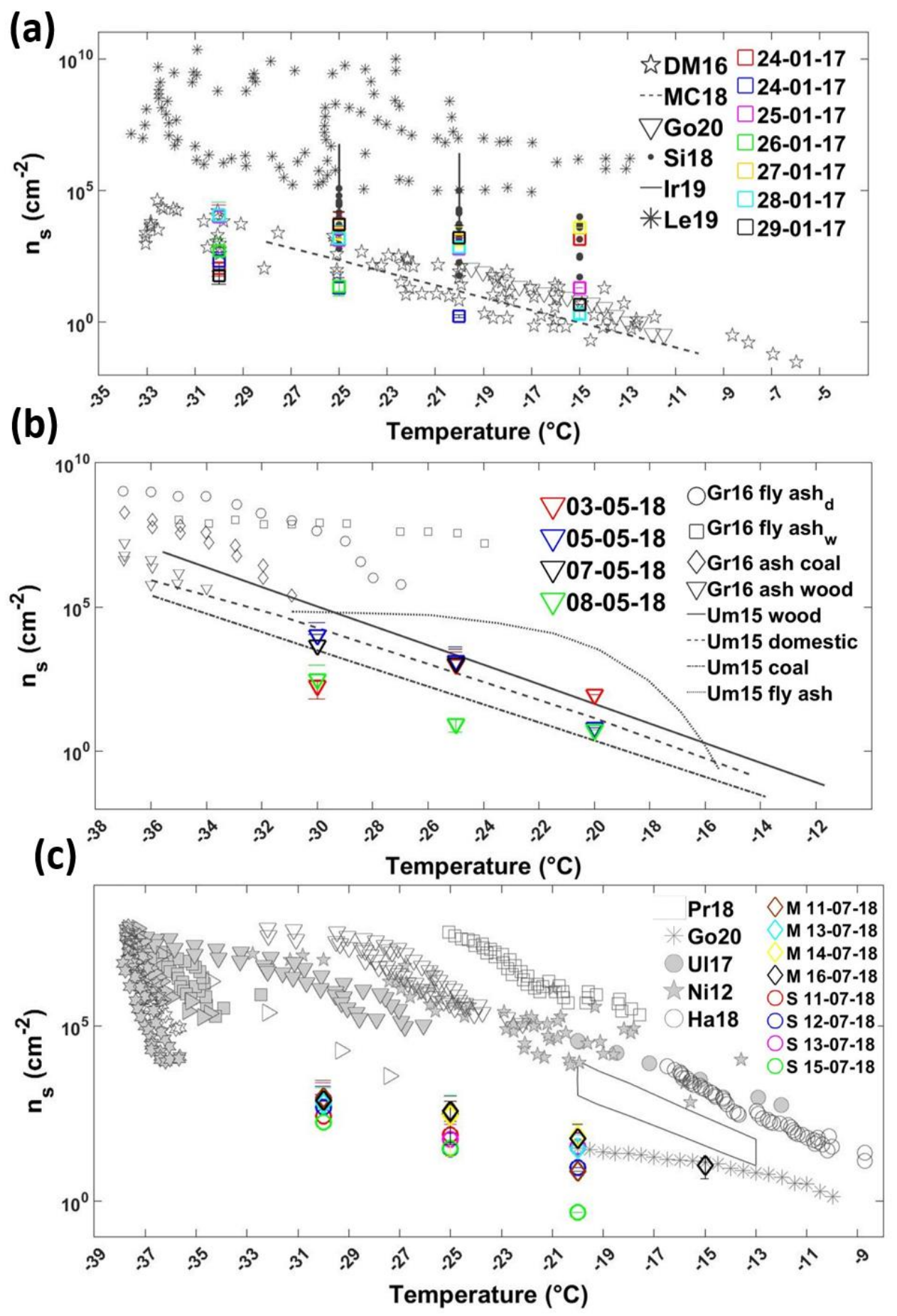

55 Figure S4. Surface active site density $\left(n_{s}\right)$ as a function of temperature for (a) MA, (b) BB, and (c) AD. Literature data is shown in gray colors. In panel (a), DeMott et al. (2016) (star), McCluskey et al (2018) (dotted line), Gong et al. (2020) (triangle), Si et al. (2018) (black point), Irish et al. (2019) line, Levin et al. (2019) (asterisk) and the colored squares correspond to the MA samples in this study. In panel (b), Grawe et al. (2016) fly ash dry 
60 (circle), fly ash wet (square), ash coal (diamond), and ash wood (triangle), Umo et al. (2015) wood (solid line), domestic (dashed line), coal (dotdash line) and fly ash (dotted line) and the colored triangles correspond to the BB samples in this study. In panel (c), Price et al. (2018) (rectangle), Gong et al. (2020) (asterisk), Ullrich et al. (2017) (solid circle), Niemand et al. (2012) (star), Harrison et al. (2018) (open circle), Atkinson et al. (2013) k-feldespar (open square) montmorillonite (solid square), $\mathrm{Na} / \mathrm{Ca}$-feldespar (open inverted triangle), quarts (solid inverted triangle), kaolinite (open triangle), chlorite (solid triangle), calcite (open hexagram), mica (solid hexagram), and the colored diamonds and circles to AD samples collected in Merida and Sisal, respectively.

\section{Calculation of surface active site density $\left(n_{s}\right)$}

The methodology employed in this study is based on Si et al. (2018).

a) Calculation of the particle density at the sampling $\mathbf{R H}\left(\rho_{\mathrm{p}, \mathrm{RH}}\right)$

$$
\boldsymbol{\rho}_{\mathrm{p}, \mathrm{RH}}=\boldsymbol{\rho}_{\mathrm{w}}+\left(\boldsymbol{\rho}_{\mathrm{p}, \mathrm{dry}}-\boldsymbol{\rho}_{\mathrm{w}}\right) \frac{1}{\mathrm{gf}^{3}}
$$

where $\rho_{w}$ is the density of water and $P_{p, d r y}$ is the density of the dry particles. $1.87 \mathrm{~g} \mathrm{~cm}^{-3}$

75 was used for marine aerosol ( $\mathrm{Si}$ et al., 2018), $2.5 \mathrm{~g} \mathrm{~cm}^{-3}$ for dust mineral particles (Wheeler et al., 2015) and $1.25 \mathrm{~g} \mathrm{~cm}^{-3}$ for biomass burning particles, it is the average between $1.1 \mathrm{~g} \mathrm{~cm}^{-3}$ and $1.4 \mathrm{~g} \mathrm{~cm}^{-3}$ reported by Li et al. (2016). $g f^{3}$ is the hygroscopic growth factor. This factor was obtained from Ming and Russell (2001), using the mean relative humidity for Sisal in January (65\%) and July (95\%), and for Merida in May

80 (65\%) and July (90\%). The particles were assumed to be composed of $30 \%$ of organic species.

b) Calculation of factor $(x)$ that relates the geometric diameter with the aerodynamic diameter.

$$
\begin{gathered}
\mathbf{D}_{\mathrm{ae}, \mathrm{RH}}=\mathbf{g f} \sqrt{\frac{\boldsymbol{\rho}_{\mathrm{p}, \mathrm{RH}}}{{ }_{\chi} \boldsymbol{\rho}_{0}}} \mathbf{D}_{\text {geo,dry }}=\mathbf{x D}_{\text {geo,dry }} \\
\mathbf{x}=\mathbf{g f} \sqrt{\frac{\boldsymbol{\rho}_{\mathrm{p}, \mathrm{RH}}}{{ }_{\chi} \boldsymbol{\rho}_{0}}} \quad \text { (S_E3) }
\end{gathered}
$$

where $D_{a e, R H}$ is the aerodynamic diameter at the sampling RH, $D_{g e o, d r y}$ the dry geometric diameter, ${ }_{\chi}$ the dynamic shape factor for a non-spherical particle shape, and $\rho_{0}$ the unit density of $1 \mathrm{~g} \mathrm{~cm}^{-3}$.

c) Calculation of $\mathbf{n}_{\mathrm{s}}$ base on the aerodynamic diameters at given $\mathbf{R H}$. 


$$
\mathrm{n}_{\mathrm{s}_{-} \mathrm{ae} \_\mathrm{RH}}=\frac{\left[\mathrm{INP}_{\mathrm{S}}\right]}{\mathrm{S}_{\text {tot,ae,RH }}}=\frac{\left[\mathrm{INP}_{\mathrm{s}}\right]}{\pi \mathrm{x}^{2} \mathrm{D}_{\text {geo,dry }}^{2} \mathrm{~N}_{\text {tot }}}
$$

where [INPS] is the concentration of INP, $S_{t o t a, a, R H}$ the total surface area based on the aerodynamic diameter at the sampling $\mathrm{RH}$, and $N_{\text {tot }}$ the total number of aerosol particles.

\section{References}

Atkinson, J. D., Murray, B. J., Woodhouse, M. T., Whale, T. F., Baustian, K. J., Carslaw, K. S., Dobbie, S., O'Sullivan, D. and Malkin, T. L.: The importance of feldspar for ice nucleation by mineral dust in mixed-phase clouds, Nature, 498(7454), 355-358, doi:10.1038/nature12278, 2013.

DeMott, P. J., Hill, T. C. J., McCluskey, C. S., Prather, K. A., Collins, D. B., Sullivan, R. C., Ruppel, M. J., Mason, R. H., Irish, V. E., Lee, T., Hwang, C. Y., Rhee, T. S., Snider, J. R., McMeeking, G. R., Dhaniyala, S., Lewis, E. R., Wentzell, J. J. B., Abbatt, J., Lee, C., Sultana, C. M., Ault, A. P., Axson, J. L., Martinez, M. D., Venero, I., SantosFigueroa, G., Stokes, M. D., Deane, G. B., Mayol-Bracero, O. L., Grassian, V. H., Bertram, T. H., Bertram, A. K., Moffett, B. F. and Franc, G. D.: Sea spray aerosol as a unique source of ice nucleating particles, Proc. Natl. Acad. Sci. U. S. A., 113(21), 57975803, doi:10.1073/pnas.1514034112, 2016.

Gong, X., Wex, H., Pinxteren, M., Triesch, N., Wadinga Fomba, K., Lubitz, J., Stolle, C., 110 Weinhold, K., Brandy, T., Müller, T., Herrmann, H. and Stratmann, F.: Characterization of aerosol particles at Cabo Verde close to sea level and at the cloud level - Part 2: Icenucleating particles in air, cloud and seawater, Atmos. Chem. Phys., 20(3), 1451-1468, doi:10.5194/acp-20-1431-2020, 2020.

Harrison, A. D., Whale, T. F., Rutledge, R., Lamb, S., Tarn, M. D., Porter, G. C. E., Adams, M. P., McQuaid, J. B., Morris, G. J. and Murray, B. J.: An instrument for quantifying heterogeneous ice nucleation in multiwell plates using infrared emissions to detect freezing, Atmos. Meas. Tech., 11(10), 5629-5641, doi:10.5194/amt-11-5629-2018, 2018.

Irish, V. E., Hanna, S. J., Willis, M. D., China, S., Thomas, J. L., Wentzell, J. J. B., Cirisan, A., Si, M., Leaitch, W. R., Murphy, J. G., Abbatt, J. P. D., Laskin, A., Girard, E. and Bertram, A. K.: Ice nucleating particles in the marine boundary layer in the Canadian Arctic during summer 2014, Atmos. Chem. Phys., 19(2), 1027-1039, doi:10.5194/acp19-1027-2019, 2019.

Levin, E. J. T., DeMott, P. J., Suski, K. J., Boose, Y., Hill, T. C. J., McCluskey, C. S., Schill, G. P., Rocci, K., Al-Mashat, H., Kristensen, L. J., Cornwell, G., Prather, K., Tomlinson, J., Mei, F., Hubbe, J., Pekour, M., Sullivan, R., Leung, L. R. and Kreidenweis, S. M.: Characteristics of Ice Nucleating Particles in and Around California Winter Storms, J. Geophys. Res. Atmos., 124(21), 11530-11551, doi:10.1029/2019JD030831, 2019.. 
Li, C., Hu, Y., Chen, J., Ma, Z., Ye, X., Yang, X., Wang, L., Wang, X. and Mellouki, A.: Physiochemical properties of carbonaceous aerosol from agricultural residue burning: Density, volatility, and hygroscopicity, Atmos. Environ., 140, 94-105, doi:10.1016/j.atmosenv.2016.05.052, 2016.

McCluskey, C. S., Hill, T. C. J., Humphries, R. S., Rauker, A. M., Moreau, S., Strutton, P. G., Chambers, S. D., Williams, A. G., McRobert, I., Ward, J., Keywood, M. D., Harnwell, J., Ponsonby, W., Loh, Z. M., Krummel, P. B., Protat, A., Kreidenweis, S. M. and DeMott, P. J.: Observations of Ice Nucleating Particles Over Southern Ocean Waters, Geophys. Res. Lett., 45(21), 11,989-11,997, doi:10.1029/2018GL079981, 2018.

Ming, Y., Russell, L.M. Predicted hygroscopic growth of sea salt aerosol. J. Geophys. Res. Atmos. 106, 28259-28274. https://doi.org/10.1029/2001JD000454, 2001.

Niemand, M., Möhler, O., Vogel, B., Vogel, H., Hoose, C., Connolly, P., Klein, H., Bingemer, H., DeMott, P., Skrotzki, J. and Leisner, T.: A Particle-Surface-Area-Based Parameterization of Immersion Freezing on Desert Dust Particles, J. Atmos. Sci., 69(10), 3077-3092, doi:10.1175/JAS-D-11-0249.1, 2012.

145 Price, H. C., Baustian, K. J., McQuaid, J. B., Blyth, A., Bower, K. N., Choularton, T., Cotton, R. J., Cui, Z., Field, P. R., Gallagher, M., Hawker, R., Merrington, A., Miltenberger, A., Neely, R. R., Parker, S. T., Rosenberg, P. D., Taylor, J. W., Trembath, J., VergaraTemprado, J., Whale, T. F., Wilson, T. W., Young, G. and Murray, B. J.: Atmospheric Ice-Nucleating Particles in the Dusty Tropical Atlantic, J. Geophys. Res. Atmos., 123(4), 2175-2193, doi:10.1002/2017JD027560, 2018.

Si, M., Irish, V.E., Mason, R.H., Vergara-Temprado, J., Hanna, S.J., Ladino, L.A., YakobiHancock, J.D., Schiller, C.L., Wentzell, J.J.B., Abbatt, J.P.D., Carslaw, K.S., Murray, B.J., Bertram, A.K. Ice-nucleating ability of aerosol particles and possible sources at three coastal marine sites. Atmos. Chem. Phys. 18, 15669-15685. https://doi.org/10.5194/acp-18-15669-2018, 2018.

Ullrich, R., Hoose, C., Möhler, O., Niemand, M., Wagner, R., Höhler, K., Hiranuma, N., Saathoff, H. and Leisner, T.: A new ice nucleation active site parameterization for desert dust and soot, J. Atmos. Sci., 74(3), 699-717, doi:10.1175/JAS-D-16-0074.1, 2017.

Umo, N. S., Murray, B. J., Baeza-Romero, M. T., Jones, J. M., Lea-Langton, A. R., Malkin, 160 T. L., O’Sullivan, D., Neve, L., Plane, J. M. C. and Williams, A.: Ice nucleation by combustion ash particles at conditions relevant to mixed-phase clouds, Atmos. Chem. Phys., 15(9), 5195-5210, doi:10.5194/acp-15-5195-2015, 2015.

Wheeler, M.J., Mason, R.H., Steunenberg, K., Wagstaff, M., Chou, C., Bertram, A.K.. Immersion freezing of supermicron mineral dust particles: Freezing results, testing 165 different schemes for describing ice nucleation, and ice nucleation active site densities. J. Phys. Chem. A 119, 4358-4372. https://doi.org/10.1021/jp507875q, 2015. 